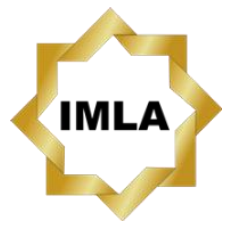

Available online:

http://journal.imla.or.id/index.php/arabi

Arabi : Journal of Arabic Studies, 4 (1), 2019, 55-64

DOI: http://dx.doi.org/10.24865/ajas.v4i1.138

\title{
PENGEMBANGAN APLIKASI PEMBELAJARAN INOVATIF DALAM PEMBELAJARAN BAHASA ARAB BERBASIS WEB
}

\author{
Pangadilan Rambe \\ Universitas Islam Negeri Sultan Syarif Kasim Riau, Indonesia \\ E-mail : dilankoerambe78@gmail.com
}

\begin{abstract}
The purpose of this study was to create a web-based application that has been developed from the introduction of animal names, fruit names and school equipment in Arabic, to find out how to validate web-based applications that have been developed in Arabic, to find out the level of application of web applications in Arabic, and to find out the effectiveness level of innovative learning applications in web-based programming languages. The population in this study was MIN 1 teachers from Pekanbaru who were dangerous with 2 people. The sample technique used was purposive sampling which is based on the criteria set by the researcher. The data collection technique used was documentation, questionnaires and interviews. For data analysis, descriptive statistics was used. Based on the results of data analysis, it can be concluded that the practicality of the application was $84.83 \%$ which indicates practical applications for MIN 1 Pekanbaru city.
\end{abstract}

Keywords: WEB based application, validity of web-based applications, application practices

\begin{abstract}
Abstrak
Penelitian ini bertujuan untuk membuat aplikasi berbasis web yang sudah dikembangkan mengenai pengenalan nama hewan, nama buah-buahan, dan peralatan sekolah dalam bahasa Arab; mengetahui bagaimana tingkat validasi aplikasi berbasis web yang sudah dikembangkan dalam bahasa Arab; mengetahui tingkat praktibilitas aplikasi berbasis web dalam bahasa Arab; dan mengetahui tingkat efektifitas aplikasi pembelajaran inovatif dalam pembelajaran bahasa arab berbasis web. Populasi dalam penelitian ini adalah guru MIN 1 Kota Pekanbaru yang berjumlah 2 orang. Teknik sampel yang digunakn adalah purposive sampling, yaitu berdasarkan kriteria yang ditetapkan oleh peneliti. Adapun teknik pengumpulan data dengan menggunakan dokumentasi, angket, dan wawancara. Analisis data dilakukan dengan menggunakan teknik deskriptif statistik. Berdasarkan hasil analisis data dapat disimpulkan bahwa tingkat kepraktisan aplikasi adalah 84,83 \% yang menunjukkan bahwa aplikasi praktis untuk digunakan di MIN 1 kota Pekanbaru.
\end{abstract}

Kata Kunci: aplikasi berbasis WEB, waliditas aplikasi berbasis web, praktibilitas aplikasi 


\section{Arabi : Journal of Arabic Studies}

\section{Pendahuluan}

Perkembangan teknologi yang pesat berpengaruh terhadap proses pembelajaran dan juga pada materi pembelajaran serta cara penyampaian materi dalam proses kegiatan belajar mengajar. Pada tahap pendidikan anak usia sekolah dasar, siswa akan cenderung lebih tertarik dengan permainan yang mudah dimainkan dan mengandung warna-warna cerah serta gambar animasi yang menarik perhatian. Dan dalam tahap ini siswa akan lebih mudah mengingat suatu bentuk atau tulisan yang memiliki ciri warna menarik dan bentuk yang komunikatif dan menyenangkan.

Hasil penelitian $R \& D$ yang dilakukan oleh Aji Arif Nugroho dkk terhadap pengembangan blog sebagai media pembelajaran pada materi trigonometri menunjukkan bahwa respon peserta didik dalam menggunakan blog sangat baik sehingga dapat digunakan sebagai alat bantu dalam pembelajaran. Dengan menggunakan komputer dan blog para pengguna bisa memperoleh ketrampilan dan pengetahuan tersendiri (Nugroho, dkk, 2017).

Pengembangan Blog sebagai media pembelajaran dengan menggunakan bantuan komputer dapat lebih memudahkan siswa untuk memperoleh pengetahuan dan keterampilan, selain lebih mudah diperoleh juga mudah untuk dipelajari ulang sehingga siswa lebih mudah menyelesaikan masalah yang disajikan (Supriadi, 2015). Web dapat dimanfaatkan oleh guru matematika sebagai media alternatif penyampaian pengetahuan, media pembelajaran online, serta solusi untuk masalah kurangnya jam pembelajaran konvensional di kelas (Herasymenko, 2016).

Rekonstruksi ulang yang dilakukan Jay R Wilson terhadap desain studio yang bersifat otentik, studio berbasis lingkungan, diakses secara daring dapat menawarkan gagasan belajar bersama, desain untuk tatap muka, mengembangkan komunikasi, serta memilih banyak topik atau fitur-fitur dengan mudah dan cepat (Wilson, 2013).

Selain itu, pengembangan media pembelajaaran bahasa Arab untuk siswa kelas X SMAN 8 Malang berbasis web luring yang dilakukan oleh Amalia Firdausia, Imam Asrori, dkk menunjukkan tingkat kelayakan 93.05\%. Produk pengembangan media pembelajran bahasa Arab luring ini menghasilkan CD yang dapat digunakan dalam model pembelajaran klasikal dan mandiri. Hal ini menunjukkan media pembelajaran luring dengan menggunakan CD lebih menarik dari media buku dalam belajar bahasa Arab.

Di sisi lain, penelitian tentang model pembelajaran Hybrid learning dalam penguasaan kosakata pada anak kelas III Madrasah Ibtidaiyah dengan menggunakan bantuan media almutho yang dilakukan oleh Nuril Mufidah dkk, menunjukkan hasil bahwa anak merasa lebih senang dan bersemangat dengan menggunakan video almutho dalam menguasai kosakata Arab. Selain itu, anak juga mampu menghafal 10 kosakata Arab dalam satu kali pertemuan (Mufidah, dkk, 2019).

Selanjutnya penelitian yang dilakukan oleh Mahyuddin Ritonga dkk, tentang pembelajaran bahasa Arab berbasis teknologi informasi dan komunikasi di kota Padang menggambarkan bahwa pembelajaran bahasa Arab menjadi efektif apabila berbasis TIK dengan model al-hāsub al-ittishāli, yaitu model pembelajaran bahasa Arab komunikatif berbasis komputer yang dikembangkan di MTs kota Padang (Ritonga, dkk, 2016). Demikian juga penelitian yang dilakukan oleh Wahida menunjukkan bahwa penggunaan kamus kamus digital sebagai sumber belajar bahasa Arab untuk mencari kosa kata dalam pembelajaran bahasa Arab dianggap lebih efektif dan efesien (Wahida, 2017).

Pembelajaran yang ada di sekolah pada umumnya masih menggunakan media dan metode pengajaran menggunakan yang tercantum pada buku. Siswa diajarkan pelajaran dasar bahasa Arab sesuai dengan kompetensi dasar yang berlaku. Tidak sedikit siswa mengalami kesulitan dalam menghafal susunan huruf dan menuliskan urutan huruf untuk membentuk suatu kata. Hal ini dapat dilihat pada saat menuliskan urutan huruf untuk menyusun nama hewan, nama buah dan peralatan sekolah masih banyak terjadi kesalahan, serta hasil nilai ulangan siswa tidak dapat mencapai nilai KKM yang ditentukan. Salah satu penyebabnya adalah kurangnya rasa ketertarikan dan kurangnya perhatian siswa untuk mengikuti pembelajaran bahasa Arab yang sedang berlangsung. Selain itu, materi yang disampaikan tidak dapat diserap dengan baik karena media yang digunakan oleh guru 
kurang menarik. Ketika hal ini terjadi pada tahap pembelajaran dasar, siswa akan mengalami kesulitan mengikuti materi-materi pembelajaran selanjutnya (Klobučar, 2014; Lytvyn, 2016).

Selain itu, media pembelajaran berbentuk aplikasi yang berbasis web dalam bahasa Arab akan membuat siswa lebih mudah mengingat materi yang disampaikan oleh guru karena disajikan dalam tampilan yang menyenangkan (Khan, 2015; Messias, 2015).

Berdasarkan beberapa hasil penelitian tersebut di atas, penting dibuat sebuah media pembelajaran berupa aplikasi berbasis web dalam pembelajaran bahasa Arab yang dapat mempermudah proses belajar siswa dengan konsep belajar sambil bermain. Oleh karena itu, sebuah penelitian yang bersifat pengembangan aplikasi berbasis web sebagai salah satu media pembelajaran bahasa arab aktif dan komunikatif sangat penting dilakukan. Berdasarkan fenomena di atas, tim peneliti menilai penting diadakan sebuah penelitian dengan tema "Pengembangan Aplikasi bahasa Arab inovatif berbasis web di Madrasah Ibtidaiyah 1 Kota Pekanbaru Riau"

Tujuan dari penelitian ini adalah untuk membuat aplikasi berbasis web yang sudah dikembangkan mengenai pengenalan nama hewan, nama buah-buahan dan peralatan sekolah dalam bahasa Arab; mengetahui bagaimana tingkat validasi aplikasi berbasis web yang sudah dikembangkan dalam bahasa Arab; mengetahui tingkat praktikabilitas aplikasi berbasis web dalam bahasa Arab; dan mengetahui tingkat efektifitas aplikasi pembelajaran inovatif dalam pembelajaran bahasa arab berbasis web.

\section{Metode Penelitian}

Metode yang digunakan dalam penelitian ini adalah metode penelitian pengembangan. Model yang digunakan adalah penelitian pengembangan model 4-D. Model pengembangan 4-D (Four D) merupakan model pengembangan perangkat pembelajaran. Model ini dikembangkan oleh S. Thiagarajan, Dorothy S. Semmel, dan Melvyn I. Semmel (1974: 5). Model pengembangan 4D terdiri atas 4 tahap utama, yaitu: Define (Pendefinisian), Design (Perancangan), Develop (Pengembangan), dan Disseminate (Penyebaran). Metode dan model ini dipilih karena penelitian ini bertujuan untuk menghasilkan produk berupa aplikasi pembelajaran bahasa Arab berupa aplikasi berbasis web. Produk yang dikembangkan kemudian diuji kelayakannya dengan uji validitas dan uji coba produk untuk mengetahui sejauh mana peningkatan motivasi belajar dan hasil belajar peserta didik setelah proses pembelajaran menggunakan media pembelajaran bahasa Arab berupa aplikasi berbasis web pada materi الاسرة. Teknik pengumpulan data yang digunakan untuk mengevaluasi dan memvalidasi aplikasi pembelajaran berupa aplikasi berbasis web yang dikembangkan, melalui tes dan angket (Tsai, 2016; Arikunto, 2010). Selain itu, kuesioner juga digunakan dalam pengumpulan data melalui seperangkat pertanyaan atau pernyataan tertulis kepada responden untuk dijawab. Sedangkan data dari angket yang berupa angka disusun menurut skala perhitungan rating scale (Riduwan, 2011).

\section{Hasil Penelitian}

Penelitian ini menghasilkan suatu produk berupa aplikasi pembelajaran inovatif bahasa Arab berbasis web yang memuat materi pembelajaran bahasa Arab tingkat pemula. Lokasi yang menjadi pusat penelitian, yaitu MIN 1 Kota Pekanbaru dengan menggunkan buku bahasa Arab kurikulum 2013 yang diterbitkan oleh pihak Kementerian Agama RI. Model pengembangan yang digunakan adalah model pengembangan 4D terdiri atas 4 tahap utama, yaitu: Define (Pendefinisian), Designe (Perancangan), Develop (Pengembangan), dan Diseminate (Penyebaran). Tahap-tahap tersebut diuraikan sebagai berikut:

\section{Define (Pendefenisian)}

Fase ini merupakan tahap awal pengembangan aplikasi pembelajaran bahasa Arab berbasis web. Tujuan pada fase ini adalah mendefenisikan masalah. Jika ada kesenjangan antara apa yang terjadi dengan apa yang diharapkan, maka diperlukan penyelidikan penyebab kesenjangan tersebut. Tahap ini dilakukan dengan menganalisis kebutuhan atau analisis masalah dalam batasan materi 


\section{Arabi : Journal of Arabic Studies}

yang akan dikembangkan. Analisis yang dilakukan meliputi analisis kurikulum, analisis karakteristik siswa, serta analisis situasi atau lingkungan sekolah (Schuetz, 2018; Uzunboylu, 2011).

Hasil wawancara dengan guru bahasa Arab Madrasah Ibtidaiyah Negeri 1 Pekanbaru menunjukkan bahwa dalam pembelajaran bahasa Arab memang minim dalam penggunaan media, dan para guru memiliki keterbatasan kemampuan dalam penggunaan media teknologi informasi dan komunikasi. Dengan demikian, adanya penelitian ini sangat bermanfaat dalam rangka peningkatan mutu sekolah, khususnya mutu guru bahasa Arab.

2. Designe (Perancangan)

Pada tahapan ini peneliti memaparkan bagaimana langkah pengembangan aplikasi pembelajaran Inovatif bahasa Arab berbasis web.

Tahapan desain aplikasi ini terdiri dari beberapa langkah, yaitu:

a. Menetapkan judul materi

Judul materi yang dibuatkan aplikasi adalah أفراد الأسرة untuk kelas IV.

b. Menyiapkan buku sumber dan buku referensi lainnya

Peneliti menggunakan buku pegangan guru yang diterbitkan oleh Kemenag Pusat serta bukubuku dan referensi lain yang diperlukan dalam pembuatan aplikasi ini. Di dalam buku pegangan guru sudah tertera rumusan standar kompetensi dan tujuan yang akan dicapai.

c. Menyiapkan animasi atau gambar yang sesuai dengan pokok bahasan

Dalam tahap ini peneliti menggunakan bantuan google search.

d. Menyiapkan audio yang dibutuhkan

Dalam tahapan ini peneliti melibatkan sejumlah mahasiswa.

3. Develop (Pengembangan)

a. Validasi Desain

Aplikasi pembelajaran inovatif bahasa Arab berbasis web yang telah didesain dan dikembangkan kemudian divalidasi oleh validator ahli media pendidikan dan ahli materi bahasa Arab dengan menggunakan angket. Angket yang digunakan terlebih dahulu divalidasi oleh ahli instrumen penelitian. Validitas instrumen angket digunakan untuk mengetahui kelayakan dari instrumen angket yang akan digunakan.

Penelitian dilaksanakan pada tanggal 3 Oktober sampai dengan 1 November 2018 di Madrasah Ibtidaiyah Negeri 1 Kota Pekanbaru. Angket yang digunakan memuat sejumlah 25 poin pernyataan yang disebarkan kepada 2 orang responden. Sugiyono (2015: 137) mengemukakan bahwa untuk keperluan analisis kuantitatif, alternatif jawaban pada angket dapat diberikan skor sebagai berikut:

Tabel 1: Alternatif Jawaban Angket

\begin{tabular}{ccc}
\hline Pernyataan & Skor Positif & Skor Negatif \\
\hline Sangat Setuju & 4 & 1 \\
Setuju & 3 & 2 \\
Tidak Setuju & 2 & 3 \\
Sangat Tidak Setuju & 1 & 4 \\
\hline
\end{tabular}

Sumber : Sugiyono (2015: 137)

Adapun tujuan dari penyebaran kuisioner ini adalah untuk mengetahui validitas dan praktibilitas aplikasi pembelajaran bahasa Arab berbasis web. Aplikasi pembelajaran inovatif bahasa Arab berbasis web yang telah didesain kemudian divalidasi oleh validator ahli media pendidikan dan ahli materi bahasa Arab dengan menggunakan angket. Angket yang digunakan terlebih dahulu divalidasi oleh ahli instrumen penelitian. Validitas instrumen angket digunakan untuk mengetahui kelayakan dari instrumen angket yang akan digunakan. Data validitas instrumen angket dapat dilihat pada Tabel 2 berikut ini: 
Arabi : Journal of Arabic Studies

Tabel 2 : Validitas Instrumen Angket

\begin{tabular}{|c|c|c|c|c|c|}
\hline No & $\begin{array}{c}\text { Jenis } \\
\text { Angket }\end{array}$ & Kriteria & Nomor Soal & $\begin{array}{l}\text { Jum } \\
\text { lah }\end{array}$ & Persentase \\
\hline \multirow[t]{2}{*}{1} & \multirow[t]{2}{*}{$\begin{array}{l}\text { Angket } \\
\text { ahli } \\
\text { media }\end{array}$} & Valid & $\begin{array}{c}1,2,3,4,5,6 \\
8,9,10,11 \\
12,13,14,16 \\
17,19,20\end{array}$ & 18 & $91,25 \%$ \\
\hline & & $\begin{array}{l}\text { Tidak } \\
\text { Valid }\end{array}$ & 7,18 & 2 & $8,75 \%$ \\
\hline \multirow[t]{2}{*}{2} & \multirow[t]{2}{*}{$\begin{array}{l}\text { Angket } \\
\text { ahli } \\
\text { materi } \\
\text { PBA }\end{array}$} & Valid & $\begin{array}{l}1,2,3,4,5,6, \\
7,8,9,11,12, \\
13,14,15,16, \\
17,18,19,21, \\
\quad 22\end{array}$ & 20 & $90,9 \%$ \\
\hline & & $\begin{array}{l}\text { Tidak } \\
\text { Valid }\end{array}$ & 10,20 & 2 & $9,1 \%$ \\
\hline \multirow[t]{2}{*}{3} & \multirow[t]{2}{*}{$\begin{array}{l}\text { Angket } \\
\text { ahli uji } \\
\text { praktika } \\
\text { litas }\end{array}$} & Valid & $\begin{array}{c}1,2,3,4,5,6, \\
8,9,11,13, \\
14,15,16,17, \\
18,20,21,22, \\
23,24\end{array}$ & 20 & $83,33 \%$ \\
\hline & & $\begin{array}{l}\text { Tidak } \\
\text { Valid }\end{array}$ & $7,10,12,19$ & 4 & $16,67 \%$ \\
\hline
\end{tabular}

Tujuan utama validasi ini adalah untuk melihat apakah produk modul sudah layak atau tidak untuk diuji cobakan. Data hasil validasi modul pembelajaran Inovatif berbasis web ini adalah sebagai berikut:

1) Ahli Media IT

Hasil penilaian oleh ahli media IT terhadap aplikasi yang telah didesain, dapat dilihat berikut ini:

Tabel 3 : Hasil Validasi Ahli IT

\begin{tabular}{|c|l|c|l|}
\hline No & Kriteria Modul & $\begin{array}{c}\text { Nilai } \\
\text { Validasi }\end{array}$ & Kriteria \\
\hline 1 & Bahasa & $90 \%$ & Sangat Valid \\
\hline 2 & Tampilan & $95 \%$ & Sangat Valid \\
\hline 3 & Audio & $90 \%$ & Sangat Valid \\
\hline 4 & $\begin{array}{l}\text { Penempatan } \\
\text { gambar/animasi }\end{array}$ & $90 \%$ & Sangat Valid \\
\hline \multicolumn{2}{|l}{ Rata-rata } & $91,25 \%$ & Sangat Valid \\
\hline
\end{tabular}

Rata-rata hasil uji validitas aplikasi pembelajaran bahasa Arab inovatif berbasis web pada tabel IV.3 menunjukkan nilai sebesar 91,25\% dengan kategori sangat valid. Hal ini menunjukkan bahwa aplikasi pembelajaran bahasa Arab yang didesain sudah sangat valid dan dapat diuji cobakan. Namun, berdasarkan komentar dan saran dari ahli media dijadikan bahan perbaikan untuk menyempurnakan aplikasi pembelajaran bahasa Arab menjadi lebih baik lagi.

2) Ahli Materi

Hasil penilaian oleh ahli materi pendidikan bahasa Arab, yaitu Muspika Hendri, MA. terhadap modul yang telah di desain adalah sebagai berikut:

Tabel 4 : Hasil Validasi Ahli Materi PBA

\begin{tabular}{|l|l|c|c|}
\hline No & Kriteria Modul & $\begin{array}{c}\text { Nilai } \\
\text { validasi }\end{array}$ & Kriteria \\
\hline 1 & Isi atau materi & $85 \%$ & Valid \\
\hline 2 & Aspek tujuan & $85 \%$ & Valid \\
\hline 4 & Bahasa & $80 \%$ & Valid \\
\hline 5 & Pendukung & $85 \%$ & Valid \\
\hline \multicolumn{2}{|l|}{ Rata-rata } & $83,75 \%$ & Valid \\
\hline
\end{tabular}


Berdasarkan tabel tersebut, jelas terlihat bahwa persentase keseluruhan penilaian ahli materi menunjukkan nilai sebesar $83,75 \%$ dengan kategori valid. Hal ini berarti aplikasi pembelajaran inovatif bahasa Arab berbasis web sudah bisa di uji cobakan.

3) Data keseluruhan (ahli media pendidika dan ahli materi)

Hasil penilaian validitas secara keseluruhan dari ahli media pendidikan dan ahli materi pembelajaran dapat dilihat pada Tabel 5.

Tabel 5 : Perhitungan Data Hasil Uji Validitas secara Keseluruhan

\begin{tabular}{|l|l|c|}
\hline No & Variabel Validitas Modul & $\begin{array}{c}\text { Persentasi } \\
\text { Keidealan }\end{array}$ \\
\hline 1 & Ahli media pendidikan & $91,25 \%$ \\
\hline 2 & Ahli materi pembelajaran & $83,75 \%$ \\
\hline Rata-rata & $87.5 \%$ (Valid) \\
\hline
\end{tabular}

Berdasarkan hasil perhitungan tersebut jelas terlihat bahwa persentase secara keseluruhan penilaian para ahli adalah valid, karena berada pada rentang 70\%-89\%, sehingga Aplikasi pembelajaran bahasa Arab inovatif berbasis web sudah layak untuk diuji cobakan. Namun saran dan komentar dari ahli dijadikan bahan perbaikan dalam penyempurnaan aplikasi ini menjadi lebih baik.

4) Perbaikan Desain

Modul yang telah divalidasi dilakukan perbaikan berdasarkan saran dan komentar dari ahli media pendidikan dan ahli materi pembelajaran untuk menghasilkan produk aplikasi yang lebih baik. Aplikasi yang dihasilkan telah mengalami beberapa revisi sesuai dengan saran validator. Pada tabel IV.6 diuraikan saran dari masing-masing validator terhadap modul yang telah divalidasi

TABEL 6 : Saran Validator terhadap Modul Pembelajaran Kimia Terintegrasi Nilai-Nilai Islam

\begin{tabular}{|c|c|c|c|}
\hline No & $\begin{array}{c}\text { Valida } \\
\text { tor }\end{array}$ & Saran & Perbaikan \\
\hline 1. & $\begin{array}{c}\text { Ahli } \\
\text { media }\end{array}$ & $\begin{array}{l}\text { 1. Gambarnya harus lebih berwarna } \\
\text { 2. Tulisannya diperbesar dan } \\
\text { diperjelas } \\
\text { 3. Audionya diperlambat ritmenya. }\end{array}$ & $\begin{array}{c}\text { Sudah } \\
\text { diperbaiki }\end{array}$ \\
\hline 2. & $\begin{array}{c}\text { Ahli } \\
\text { materi }\end{array}$ & $\begin{array}{ll}\text { 1. } & \text { Qiraahnya diperjelas } \\
\text { 2. } & \text { Mufradatnya ditambah } \\
\text { 3. } & \text { Masukkan KD dan Indikatornya }\end{array}$ & $\begin{array}{c}\text { Sudah } \\
\text { diperbaiki }\end{array}$ \\
\hline
\end{tabular}

\section{Pembahasan}

Berdasarkan uraian dari data hasil penelitian, permasalahan yang dihadapi di madrasah yaitu masih minimnya penggunaan media pembelajaran berbasis web atau multimedia. Hal ini dapat dilihat di gejala-gejala yang telah disurvei oleh peneliti sebelumnya.

1. Analisis Validasi Modul

a. Validasi Ahli Media Pendidikan

Hasil analisis data menunjukkan bahwa aplikasi pembelajaran bahasa Arab yang telah divalidasi dikategorikan Sangat Valid dengan nilai 91,25\%. Hasil validasi yang dilakukan oleh ahli media pada setiap aspeknya sebagaimana dianalisis secara kuantitatif dapat diinterpretasikan sebagai berikut:

1) Aspek bahasa

Aspek bahasa yang meliputi: penggunaan bahasa yang mudah dipahami siswa dan komunikatif mendapat nilai $90 \%$ dengan kategori sangat valid. Dengan demikian, aspek bahasa yang digunakan dalam menyampaikan materi pada aplikasi pembelajaran bahasa Arab sudah komunikatif sehingga mudah dipahami oleh siswa.

2) Aspek tampilan

Aspek tampilan meliputi: kemenarikan home atau pembuka aplikasi, tampilan isi, pemilihan warna, tampilan teks dan gambar, layout pengetikan, penggunaan background termasuk kategori 
sangat valid dengan persentase 95\%. Dengan demikian, tampilan aplikasi ini sudah bagus, sangat sesuai, sudah tepat, sehingga diharapkan dapat membuat siswa tertarik dan merasa senang belajar bahasa Arab menggunakan aplikasi ini.

3) Aspek Audio

Aspek Audio yang meliputi penggunaan suara termasuk kategori sangat valid dengan persentase $90 \%$. Dengan demikian penggunaan suara dalam aplikasi ini yang bertujuan sebagai pelengkap dan pendukung penyampaian materi sudah sesuai dengan teori, sangat jelas.

4) Aspek Penempatan Gambar

Aspek penempatan gambar dan visual termasuk kategori sangat valid dengan persentase 90\%. Dengan demikian penggunaan gambar dan visual dalam aplikasi ini yang bertujuan sebagai pelengkap dan pendukung penyampaian materi sudah sesuai dengan teori, sangat jelas.

b. Validasi Ahli Materi PBA

Hasil analisis data menunjukkan bahwa aplikasi pembelajaran bahsa Arab inovatif berbasis web yang dihasilkan dikategorikan valid dengan nilai validitas adalah $83,75 \%$. Hasil validasi yang dilakukan oleh ahli materi pembelajaran pada setiap aspeknya sebagaimana dianalisis secara kuantitatif dapat diinterpretasikan sebagai berikut.

1) Aspek isi atau materi

Aspek isi atau materi yang meliputi: kesesuaian judul materi, kesesuaian materi dengan kurikulum, keterkaitan antar konsep, dan penjabaran materi termasuk kategori valid dengan persentase $85 \%$. Dengan demikian, materi yang terdapat pada aplikasi sudah sesuai dengan kurikulum yang berlaku, keterkaitan antar konsepnya sudah baik, dan penjabaran materinya sudah lengkap, mendalam, akurat, dan sesuai dengan tingkat pemahaman dan perkembangan siswa.

2) Aspek tujuan

Aspek tujuan meliputi kejelasan tujuan pembelajaran dan tujuan soal yang dapat mengukur ketercapaian kompetensi pada aplikasi termasuk kategori valid dengan persentase $85 \%$. Dengan demikian, aspek tujuan pada aplikasi dapat dikatakan sudah memiliki tujuan yang jelas dan soalsoal yang terdapat di dalamnya dapat mengukur ketercapaian kompetensi siswa.

3) Bahasa

Aspek bahasa dalam menyampaikan materi pada aplikasi termasuk kategori valid dengan persentase $80 \%$. Dengan demikian bahasa yang digunakan dalam modul untuk menyampaikan materi pelajaran sudah komunikatif dan mudah dipahami siswa

4) Pendukung

Aspek pendukung modul meliputi penggunaan gambar, audio, grafik dan simbol serta tersedianya soal latihan pada setiap akhir kegiatan belajar termasuk kategori sangat valid dengan persentase $85 \%$. Dengan demikian, aspek pendukung dapat membuat aplikasi menjadi lebih baik, karena penyajian materi didukung oleh gambar, grafik, simbol, dan audio yang sangat sesuai dengan materi ditambah juga dengan tersedianya soal latihan di semua akhir kegiatan belajar sehingga diharapkan tujuan pembelajaran dapat tercapai dengan baik.

Dari penilaian ahli media dan ahli materi diperoleh nilai rata-rata sebesar 87,5\% dengan kategori Valid. Hal ini membuktikan bahwa aplikasi yang didesain telah dinyatakan valid oleh validator karena telah memenuhi syarat-syarat dan telah mengalami perbaikan-perbaikan sehingga dapat di uji cobakan untuk selanjutnya digunakan sebagai media pembelajaran bahasa Arab inovatif.

Selain pengisian angket uji validitas media dan uji validitas materi, validator juga memberikan saran dan kritik demi terciptanya produk aplikasi yang baik. Setelah beberapa kali perbaikan berdasarkan catatan atau saran dari validator sampai memperoleh kriteria valid dan dinyatakan layak digunakan dilapangan tanpa revisi, maka peneliti melanjutkan langkah penelitian selanjutnya yaitu tahap uji coba aplikasi. 


\section{Arabi : Journal of Arabic Studies}

c. Analisis Praktibilitas Aplikasi

Pada tahap ini merupakan tahap uji coba yang dilakukan peneliti untuk menguji kepraktisan produk aplikasi yang telah divalidasi. Aplikasi pembelajaran bahasa Arab dengan materi أفرد الأسرة oleh guru dinyatakan kategori praktis dengan nilai $84,83 \%$. Adapun perincian nilai pada setiap aspeknya sebagaimana dianalisis secara kuantitatif dapat diinterpretasikan sebagai berikut:

1) Aspek tampilan

Aspek tampilan aplikasi meliputi: tampilan desain aplikasi dan penggunaan gambar termasuk kategori praktis dengan persentase $85 \%$. Dengan demikian, hal ini berarti tampilan pada aplikasi sudah baik, sesuai, tepat dan menarik sehingga diharapkan siswa merasa senang dan tertarik belajar menggunakan aplikasi ini.

2) Aspek pemahaman siswa terhadap materi

Aspek pemahaman siswa terhadap materi pada aplikasi termasuk kategori praktis dengan persentase $89 \%$. Dengan demikian, materi yang terdapat pada aplikasi dapat dipahami oleh siswa dengan mudah, sehingga hal ini akan memudahkan siswa untuk mengerjakan setiap soal yang tertera di aplikasi tersebut.

3) Aspek minat

Aspek minat yang meliputi keterkaitan siswa terhadap aplikasi dan pelajaran bahasa Arab termasuk kategori praktis dengan persentase $85 \%$. Dengan demikian aplikasi pembelajaran bahasa Arab dapat membuat siswa tertarik belajar bahasa Arab menggunakan aplikasi, hal ini karena penjabaran materinya mudah dipahami siswa dan bahasa yang digunakan juga komunikatif.

4) Aspek penggunaan aplikasi

Aspek penggunaan aplikasi yang meliputi kepraktisan penggunaan aplikasi dan kemampuan aplikasi untuk meningkatkan keaktifan siswa termasuk kategori praktis dengan persentase $80 \%$. Dengan demikian, aplikasi pembelajaran bahasa Arab inovatif berbasis web praktis digunakan karena berbentuk media audio visual.

5) Aspek bahasa

Aspek bahasa yang digunakan dalam aplikasi termasuk kategori sangat praktis dengan persentase $85 \%$. Dengan demikian bahasa yang digunakan dalam menyampaikan materi pada aplikasi mudah dimengerti dan sangat komunikatif.

6) Aspek materi

Aspek materi yang meliputi penyajian materi termasuk kategori sangat praktis dengan presentase $85 \%$. Dengan demikian, materi yang disajikan pada aplikasi sudah sesuai dengan indikator pembelajaran dan disajikan secara sistematis.

Hasil penilaian oleh validator uji praktibilitas tersebut menunjukkan bahwa secara keseluruhan aplikasi ini Praktis dalam menyampaikan materi bahasa Arab untuk tingkat dasar khususnya siswa kelas IV. Siswa diharapkan dapat belajar bahasa Arab dengan mudah dan praktis serta menyenangkan.

\section{Simpulan}

Berdasarkan hasil penelitian yang telah dilakukan dapat disimpulkan bahwa telah dihasilkan sebuah aplikasi pembelajaran bahasa Arab inovatif berbasis web yang bersifat komunikatif, praktis, dan menyenangkan, yaitu: 1) Tingkat kevalidan aplikasi adalah 87,5\%. Nilai ini menunjukkan bahwa aplikasi telah valid dan bisa diuji cobakan di MIN 1 Kota Pekanbaru; 2) Tingkat kepraktisan aplikasi adalah $84,83 \%$. Nilai ini menunjukkan bahwa aplikasi praktis untuk digunakan di MIN 1 Kota Pekanbaru.

Jenis pengembangan desain model yang dipakai dalam penelitian ini adalah model Four D's, yang terdiri dari empat langkah: define, desain, development, dan dessimination. Produk (Model Pembelajaran Bahasa Arab) yang dihasilkan melalui proses pengembangan ini adalah perangkat pembelajaran bahasa Arab yang mencakup: silabus bahasa Arab, RPS bahasa Arab, dan penilaian bahasa Arab. 
Berdasarkan penelitian yang telah dilakukan dapat disarankan hal-hal berikut: 1) Peneliti menyarankan agar aplikasi ini dapat digunakan dan dikembangkan kembali, karena sifat dasar aplikasi ini adalah semakin sering digunakan dan divalidasi maka produknya akan semakin matang dan berkembang. 2) Aplikasi ini sebaikanya dikembangkan lebih lanjut dengan melakukan eksperimen menggunakan kelas pembanding agar kualitas aplikasi ini benar-benar teruji dalam hal pemanfaatannya.[]

\section{Daftar Rujukan}

Arikunto, Suharsimi. 2010. Manajemen Penelitian. Jakarta: Rineka Cipta.

Herasymenko, I. 2016. "Used distance learning technologies”, Proceedings, 13th International Conference on Modern Problems of Radio Engineering. Telecommunications and Computer Science (TCSET).

Khan, B.H., M. Ally. 2015. International Handbook of E-learning, Volume 1: Theoretical, Perspective and Research. London, New York: Routledge, Taylor \& Francis Group.

Klobučar, T., D. Gabrijelčič., V. Pagon. 2014. Cross-border e-learning and academic services based on eIDs: Case of Slovenia, eChallenges.

Lytvyn, V., et al. 2016. "Distance learning method for modern youth promotion and involvement in independent scientific researches", Proceedings, IEEE First International Conference on Data Stream Mining \& Processing (DSMP).

Messias, I., L. Morgado., M. Barbas. 2015. “Students' engagement in Distance Learning: Creating a scenario with LMS and Social Network aggregation", ProceedingS, International Symposium on Computers in Education (SIIE).

Mufidah, Nuril., et.al. 2019. "Hybrid Learning dalam Pembelajaran Kosa Kata Bahasa Arab Pada Anak Berbantuan Media Al-Mutho", Almudarris, Vol. 2, No. 1.

Nugroho, Aji Arif., dkk. 2017. "Pengembangan Blog Sebagai media pembelajaran matematika”, Al-Jabar: Jurnal Pendidikan Matematika, Vol. 8, No. 2.

Nugroho, Arif Aji. 2017. "Pengembangan Media Pembelajaran Berbantuan Blog Pada Materi Trigonometri”, Thesis, UIN Lampung.

Riduwan. 2011. Skala Pengukuran Variabel-Variabel Penelitian. Bandung: Alfabeta.

Ritonga, Mahyuddin., dkk. 2016. "Pembelajaran bahasa Arab berbasis tekhnologi informasi dan komunikasi di kota Padang", Arabiyat, Vol. 3, No. 1.

Schuetz, Rachael Law., Gina Biancarosa., \& Joanna Goode. 2018. "Is Technology the Answer? Investigating Students' Engagement in Math", Journal of Research on Technology in Education.

Sugiyono. 2013. Metode Penelitian Pendidikan. Bandung: Alfabet.

Supriadi, N. 2015. "Pembelajaran Geometri Berbasis Geogebra Sebagai Upaya Meningkatkan Kemampuan Komunikasi Matematis Siswa Madrasah Tsanawiyah (MTs)", Al-Jabar: Jurnal Pendidikan Matematika, Vol. 6, No. 2.

Thiagarajan, S., D.S. Semmel., \& M.I. Semmel. 1974. Instructional Development for Training Teachers of Exceptional Children: A Sourcebook. Indiana: Indiana University.

Tsai, I-C., et.al. 2016. "Developing Taiwan innovative interactive distance learning model: Empirical studies", Proceedings, 11th International Conference on Computer Science \& Education (ICCSE). 
Arabi : Journal of Arabic Studies

Uzunboylu, H., H. Bicen., N. Cavus. 2011. "The efficient virtual learning environment: a case study of Web 2.0 tools and Windows Live Space”, Computers \& Education, Vol. 56.

Wahida. 2017. "Penggunaan kamus cetak dan kamus digital sebagai sumber belajar bahasa Arab", At-Turats, Vol. 11, No. 1.

Wilson, Jay R. 2013. "Course Design using an Authentic Studio Model / Restructuration de cours au moyen d'un authentique modele de studio de design", CJLT Canadian Journal of Learning and Technology, The Canadian Network for Innovation in Education (CNIE). 